\title{
Lean Thinking and Industrial 4.0 Approach to Achieving Construction 4.0 for Industrialization and Technological Development
}

\author{
Amusan Lekan 1,2*(D), Aigbavboa Clinton ${ }^{3}$, Ojo Sunday Isaac Fayomi ${ }^{4}$ and Owolabi James ${ }^{1}$ \\ 1 Building Technology Department, College of Science and Technology, Covenant University, KLM 10, \\ Canaanland, Ota, Ogun State PMB 1023, Nigeria; james.owolabi@covenantuniversity.edu.ng \\ 2 Department of Construction Management \& Quantity Surveying, Faculty of Engineering and the Built \\ Environment, University of Johannesburg, Doorfoiten Campus, Maropeng 198, South Africa \\ 3 CIDB Centre of Excellence \& Sustainable Human Settlement and Construction Research Centre, \\ Department of Construction Management \& Quantity Surveying, Faculty of Engineering and the Built \\ Environment, University of Johannesburg, Doorfoiten Campus, Maropeng 198, South Africa; \\ caigbavboa@uj.ac.za \\ 4 Department of Mechanical Engineering, College of Engineering, Covenant University, KLM 10, \\ Canaan-Land, Ota, Ogun State PMB 1023, Nigeria; ojo.fayomi@covenantuniversity.edu.ng \\ * Correspondence: lekan.amusan@covenantuniversity.edu.ng; Tel.: +234-80-3074-3025
}

Received: 15 September 2020; Accepted: 18 October 2020; Published: 28 November 2020

\begin{abstract}
The construction industry is responsible for the infrastructural and physical development of nations and plays a pivotal role in determining economic equilibrium of nations of the world; hence, there is a need for constant evolving of advanced ways of carrying out construction operations. The concept has led to the evolution of Construction 4.0, which entails harmonizing disruption in technological applications to enhance construction productivity. The study, therefore, provides an attempt at evolving an enhanced approach to improve construction processes and resource management through application of lean construction and Industry 4.0. The purposive sampling method was used in this study to collect data. The data collection instrument consists of a structured questionnaire designed in a Likert scale of 1 to 5 distributed to 100 construction professionals through an online method that is actively involved in construction operations. The following parameters were censored and profiled, while the results are in tables and charts. The parameters include areas of lean thinking that could enhance Construction 4.0, areas of disruption in Industry 4.0 that influence Construction 4.0 advancement and parameters for practical integrating of lean thinking approach and Industry 4.0. Additionally, the influence of Industry 4.0 in technological development for the construction industry, disruptive innovation of Industry 4.0 and gains towards Construction 4.0. Furthermore, the relevance of Construction 4.0 in construction productivity, the importance of Construction 4.0, industrial application drivers in achieving Construction 4.0, future of Construction 4.0, achieving automation goal in construction and performance expectation of lean thinking and Industry 4.0 in the construction industry are found necessary. Simple percentage, Spearman rankings, Chi-square test, Student-T test, Mann-Whitney-U test and Relative Agreement and Importance index are the tools used to process the data. The study discovered, among others, the veracity of contingency approach in harnessing attributes of the lean thinking concept and disruptive applications in achieving Construction 4.0. The study recommends the application of the hybrid model suggested in the study as a guide to deployment of an application that could help in industrial productivity.
\end{abstract}

Keywords: construction 4.0; industrialization; disruption; lean thinking; technology; building informatics 


\section{Introduction}

The construction industry, according to Ref. [1], consists of $99.8 \%$ of European companies with six percent GDP and employing 70\% of the entire European industry's industrial workforce. GDP is the main reason the industry is the centre point of disruptions by the industrial revolution. The construction industry is always the centre of innovative technology, and the construction industry, in recent times, has become the focal point of attraction all over the world considering the background of various innovative ideas introduced in the form of cutting edge technologies. Moreover, Refs. [1,2] opined that the construction industry is at the edge of an industrial breakthrough. There have been technologies and innovative ideas that have enhanced construction practices. For instance, Refs. [3,4] posited on the advent of productivity enhancement through innovation brought about by Industry 4.0, and the phenomenon has changed the game through the application of conventional tools. The introduction of Building Information Modelling (BIM) has also produced a tremendous impact on building and construction activities, and in $[2,5,6]$, it is argued that innovations have produced a tremendous impact on building construction work, motivation and productivity, which had drooped before Industry 4.0 productivity enhancement. The productivity enhancement comes in the construction practice through innovation in design and construction of buildings.

Meanwhile, innovations in design, tendering and building construction has changed the route of the game in the last few years. Similarly, Refs. [7-9] supported the view that more results are visible in the aspect of design and actual construction in building and general construction works. However, the innovations being a game-changer in the building construction and engineering practice has led to enhanced productivity and the saving of many working hours that could have been wasted, and this was due to the application of conventional tools [10].

Additionally, on the note that the introduction of new and conventional tools had accelerated disruption in the administration and performance of previous tools or practice in recent time. For instance, the introduction of BIM, lean concept and building informatics has produced a tremendous impact on the design, management and construction of infrastructures [9,11]. Therefore, the study explored the place of disruptive innovations in the attainment of sustainable development goal in the construction industry using an industrial revolution as a focal point to achieve sustainable development goal 9. Therefore, in Refs. [9,12], an urgent need for the introduction of disruptive innovation was advocated. Moreover, technological disruption often comes through the fourth industrial revolution, in a bid to create sustainable technological development and sustainable infrastructures. Therefore, there is a need to connect technological disruption, sustainable development and the fourth industrial revolution. Identification of the major link connecting the concepts of Industry 4.0 and lean concept is necessary because the three concepts relate to each other. It follows "means" to an "end" order. The "means" refers to the fourth industrial revolution (I4.0). The "means" is one of the active drivers that lead to an "end". An "end" is the sustainable development, smart and resilient infrastructure, energy-efficient 3D application, infrastructure among others Refs. [4,5,7,8]. The driver is the fourth industrial revolution that leads to the advent of cutting edge innovation and technology. Therefore, infrastructural development, introduction of the innovation and strategies are the pivotal key to achieving the Sustainable development goal 9 of sustainable infrastructure. However, the industrial revolution induces technological development while the digitalization of the production process is necessary for achieving Sustainable Development Goal 9; this view was supported by [1-3].

Nevertheless, in order to achieve sustainable infrastructure and technological development, there should be a paradigm shift in the direction of innovation intervention through Industrial 4.0 (I4.0). Some parameters are of the essence when the issue of a means to an end in achieving sustainable infrastructure of SDG goal 9 arises. Some of the issues include the introduction of exponential technologies for integrating cutting edge technologies, value orientation, value reengineering, terotechnology, vertical integration and horizontal application of disruptive innovation of smart technologies, among others. This view is in Refs. [1,2,9]. The study has contributed to knowledge by presenting a hybrid model spotlighting the lean and Industry 4.0 applicability to bring about 
Construction 4.0 revolution. The study outlined the innovations induced by Construction 4.0, the relevance of Construction 4.0 (C4.0) and lean thinking on construction productivity, drivers in achieving Construction 4.0 (C4.0) and parameters for effective integration of the lean thinking approach and Industrial 4.0 among others. It can find application in decision making by policymakers, industry and literary research. The study adopted a survey design method, while random sampling techniques are adopted to pick 100 samples of the respondents. The following category of respondents are engaged in the study: the production managers, production supervisors and quality control officers. The results collated were analysed with a simple percentage, spearman rankings, Chi-square test, Student-T test, Man Whitney-U test, Relative Agreement and Importance index. The study discovered, among other things, the veracity of the contingency approach in harnessing attributes of the lean thinking concept and disruptive applications in achieving Construction 4.0. The study recommends the application of hybrid model suggested in the study as a guide to deployment of an application that could help in industrial productivity.

\section{Aim and Objectives of the Study}

This research application aims to explore the operationalization of lean thinking and Industrial 4.0 concepts. It is necessary to achieve advanced industrialization and technological development through Construction 4.0 (C4.0). There is a need to articulate the research objective at this point. The objectives are from the gaps identified in the reviewed pieces of literature. Some of the objectives are to achieve the following tasks:

i. Investigate the influence of Industry 4.0 (I4.0) and lean thinking on technological development for the construction industry.

ii. Examine disruptive Industry 4.0 (I4.0) innovations induced by Construction 4.0 (C4.0).

iii. Identify the relevance of Construction 4.0 (C4.0) and lean thinking on construction productivity.

iv. To study areas of technological disruptions in lean concept that influences Construction 4.0 (C4.0) enhancement.

v. Examine Industrial Application Drivers in Achieving Construction 4.0 (C4.0).

vi. Study the future of Construction 4.0 (C4.0) in achieving the automation goal in construction.

vii. Identify performance expectation of lean thinking and Industry 4.0 (I4.0) in construction industry.

viii. Parameters for effective integration of lean thinking approach and Industrial 4.0

\subsection{Literature Review}

\subsubsection{Industry 4.0 (I4.0)}

There is an increase in technological advancement all over the world since the beginning of the 19th century. The advances are possible through the construction industry being the epicentre of technological development. In the wake of the Industry 4.0 advances, Industry 4.0 has been the game-changer that alter the traditional practice of digital innovations. In Ref. [12], Industry4.0 is an essential tool that has enhanced the supply chain. Moreover, Refs. $[13,14]$ stressed the importance of Industry 4.0 in enhancing the supply chain of technological tools and innovations and smart manufacturing. Industry 4.0 leads to the advent of application of IoT in the creation of smart and intelligent manufacturing. The application of Industry 4.0 has led to the eruption of several inventions in the construction industry. Various applications enhance industrial production, which cut across areas of operations which includes decision making, design, planning, control and monitoring. In decision making, Ref. [13] stated that decision making using technology-based tools has enhanced data analysis, and this is one of the reasons big data analytics companies are gaining ground.

In Ref. [15], it was argued that there are systems for checking and scrutinizing data quality before use which entails machine to machine interaction which tends to produce an enhanced output that the majority of researchers of machine learning of industrial application are depending. 
However, Ref. [16] opined that machine to machine communication in recent times had enhanced industrial productivity, considering the introduction of a plethora of industrial tools created through Industry 4.0 innovations. Moreover, among the signification contributions to the world through Industry 4.0 is artificial intelligence and robotics. Artificial intelligence and robotics application have enhanced productivity in the manufacturing sector of many nations worldwide, especially in material and product manufacturing. In construction materials and product manufacturing, Industry 4.0 has led to the application of a new product strategy and the introduction of sophisticated tools and systems Refs. [16,17].

Furthermore, Industry 4.0 has made a tremendous impact on the emergence of advanced systems and technologies that could enhance industrial productivity. For instance, Ref. [16] researched the technological impact of Industry 4.0 and identified the following parameters as the impact of Industry 4.0 on technological development so far; some of the parameters include advanced process control, advanced production quality measurement mechanism, quality control systems and a smart production system. According to the submissions of Refs. [15-17], the ultimate aim of the application of Industry 4.0 is technological development, which is the type that enhances output and technological adaptation that has continued to be the trend in advanced countries. Similarly, Refs. [17,18] posited that most of the success recorded in the industrial sector of the American economy revolves around technological enablement on account of Industrial 4.0. However, the opinion is that technological innovation diffusion is the epicentre of industrialization. Achievement of innovation, therefore, is possible through digitalization and management of invention. It is one of the sure ways that industrialization is achievable.

Similarly, an adequate policy framework is necessary for the proper implementation of gains of resultant development on account of Industry 4.0. Therefore, Industry 4.0 can assist in maximizing opportunities and challenges. In Ref. [19], the massive exploitation of internet resources and the creation of an industrial, technological approach and also the application of the Industrial internet were advocated. The Industrial internet can increase industrial productivity through information Telecommunication Technology production system to produce digitalized product and services. Finally, Industry 4.0 has the capability of changing the landscape of industrial productivity, efficiency and building models Ref. [19].

\subsubsection{Lean Thinking}

There have been several attempts by researchers in studying the application of lean thinking in construction with the formulation of a model that could guide in the study of lean thinking within the context of building projects [18]. Moreover, in Ref. [19], the application of the lean thinking concept in construction works was researched. Lean thinking is a system that maps values with users' requirements. There is always continuous demand for quality cost and time control on-site; this is in a bid to eliminate waste at all facets of construction. The resultant effect of lean construction adoption will enable the client to obtain value for money. In Refs. [19,20], lean construction was described, according to [16], as a Japanese initiative that assists in creating value for money through value engineering. The system ensures that quality and values belong to the client with the ultimate goal of waste elimination. Additionally, Refs. $[16,17]$ described the application of the lean concept as being first practised in Japan. In Ref. [13], the lean concept was then described as the Toyota production system that tends to permit the effectiveness of production operation. Many industries all over the world are adopting the Toyota production system to increase their production effectiveness. Similarly, the lean concept has been in application in lean manufacturing to curtail wastage of resources such as raw material, cost, money and machinery. In Ref. [21], an aspect of the lean concept in lean manufacturing as an act of eliminating waste in construction and production processes was adopted and effectively described. Application of lean concept in construction has to be viewed from the customers' perspective back to the product to eliminate waste. 


\subsubsection{Operational Principles of the Lean Thinking Concept}

The philosophy of lean thinking is basically to eliminate waste and maintain quality. The philosophy involves five cardinal objectives, according to Ref. [17]. The structure of the lean principle is explained. The objectives include: value specification, value configuration and tagging, aligning of value-creating actions points, sequencing of operations and the carrying out of outlined actions. The objectives stated has formed the basis for the benchmarking of the lean principle Ref. [16]. Moreover, Ref. [17] described the principles to include: formulating value based on customer perspectives, systematically creating procedures and steps that are necessary for value creation and working out and implementing actions that encourage value flow in the system, removing waste and unwanted output in the system. The implementation principle is in the following order value creation, value streaming, process flow, and activity pull and operation/process goal perfection.

Lean Thinking Value Creation from the Customer's Perspective

One of the essential attributes of lean thinking adoption is taking a customer or end-user of a product inclusion at the beginning of production process seriously; this is achievable by taking customers' objectivity into process formulation and product configuration. In the lean thinking concept, value creation and addition assist in creating the ability to identify customer or user needs and the risk involved and the response to fulfil the desire of the users [17]. In lean thinking, defining value from the customer perspective warrants defining value from end-users, customers, stockbrokers, clients, marketers and the like. It is this value that determines how much money the customer is willing to pay for the product and services. Value is also product-specific, and it is only meaningful when expressed in terms of a specific product [18]. The idea behind drafting customer ideas into product and system value configuration is to enable quality enhancement of quality and quality incorporation into product configuration and development. Therefore, the incorporation of low quality into the construction process tends to enhance construction productivity [19-22].

Similarly, benchmarking and delineation of structure across the mapped value stream is another critical concept; identification of value stream across the production process is germane when benchmarking and creating value in the lean thinking concept. In value streaming, it is imperative to define a set of objectives, design order and benchmarked required raw materials; this is necessary for creating value for money for the end-users from design stage to product delivery stage [16,23-26]. A value stream is significant in assisting in creating detail about process configuration and usage Ref. [27-29].

\subsubsection{Construction $4.0(\mathrm{C} 4.0)$}

Construction 4.0 is a new evolving state of construction practice which entails a revolution that incorporates digitalization in construction. Construction 4.0 involves the new application of digitalization at various stages of construction works. Refs. [30-32] Posited that, it involves the application of building informatics, construction informatics, BIM, construction information artificial intelligence, data analytics and robotics. In Refs. [22,24,25,33] Construction 4.0 was described as the one that involves the application of technologies, such as social media, mobility, analytics, cloud [SMAC], robotics, artificial intelligence, augmented knowledge and virtual reality, in expressing construction phenomenon and new areas of practice.

\subsubsection{The Concept of Circular Economy (C.E.)}

The concept of a circular economy has been increasing in attention and application since early 1970. The current economic system involves the input of resources and output in the form of consumer goods Ref. [30,34], Leveraging on the works of Ref. [30,31], it is described how the interplay of natural resources can influence the industrial productivity. The economy and environmental equilibrium is possible, and there is a tendency for coexistence and balance. The concept of the creation of 
peace between systems gave birth to the idea of the circular economy. The introduction of some features into a circular economy leads to the notion of loop economy. Loop economy is similar to the lean concept presented in this study; the two views share identical characteristics of waste elimination and efficient resource allocation. Additionally, loop economy dictates a strategy that is possible for industrial transformation, regional job provision and delineation of the industrial economy. The operationalization of circular economy concept variables leads to summarizing the circular economy according to the Mc Arthur Foundation in Ref. [35] as a type of industrial economy set up for economic transformation, which has the capability of refreshing designs and functions for the fulfilment of industrial change. This definition dovetailed into the meaning and function of the lean concept and Industry 4.0. Therapeutic characteristics of the circular economy encourage product retention and management. It promotes the flow of materials and the utilization of energy for restoration. Germany was a forerunner in the application of a circular economy into national laws with the enactment of the waste management act. In Ref. [32], the author posited that the integration of concepts through an expression of the circular economy promotion law of China is further enhanced. The circular economy concept has led to the introduction of automation into the production sector of the country such as Singapore, Malaysia, Korea, Germany and many other countries [33-35]. In Ref. [32], the author posited that the integration of concepts through an expression of the circular economy promotion law of China is further enhanced.

\subsubsection{Open Innovation}

Open innovation provides an alternative opportunity for innovation adoption and diffusion. Open innovation has a policy that tends to make firms gain access to innovative research and development Ref. [35]. Design in the context of the evolutionary process refers to the learning process that enables interdisciplinary collaboration of resource aggregation for project implementation Ref. [36,37]. The open innovation approach enables knowledge diffusion and flow. It controls the inflow of knowledge and outflow of knowledge (output). In Ref. [38], the dynamic nature of Open Innovation (OI) is necessary. A flexible and dynamic character is needed to enable a positive impact on business productivity and economic performance. It allows resource sharing and risk-sharing. In Refs. [38-41], innovation is described as an integrated approach to idea generation and processing. However, the following challenges are peculiar to O.I. the challenges are as follow: a digital barrier: the technological expansion issue, the technical transfer issue, bureaucratic logjam and the difficulty associated with innovation, among others, which is further corroborated by works of Ref. [39,40,42].

\subsubsection{Sustainable Development}

Sustainable development connects to the development of the environment in a way that the existing natural environment undergoes preservation for the present generation without jeopardizing the chances of future generation meeting their needs. In Ref. [43], sustainability was described as the consumption of today with the future in mind. Sustainable development then is the development that is environmentally compliant and which is achievable through knowledge integration of economic and environmental variables. Sustainable development, therefore, according to Ref. [44], includes human-made capital, stocks, natural and social-cultural issues that have the potential of integrating into a model that could bring economic development.

\section{Materials and Methods}

In the context of this research study, primary data were engaged from sampled production managers, production supervisors, quality control officers and information communication officers that are on the ground at the selected locations of the research. Additionally, survey materials adopted a structured questionnaire design in a closed structure manner as carried out in similar previous studies such as Ref. $[13,14,16]$. 
The research sample used in the context of this study consists of respondents that are working in the production sector as supervisors, quality control officers and production managers. Therefore, the population frame of 150 consumer goods manufacturing companies was adopted, out of which a sample size of 100 respondents assisted in the processing of data for the analysis. The respondents belong to the category of workers that are involved in the manufacturing processes of the companies.

Most of the production managers and supervisors have an adequate practical background which enables them to be suitable for the research. The respondents' minimum academic qualification is a Diploma masters and PhD degree in a technological and engineering-related field. Furthermore, the majority of the respondents have adequate production and manufacturing experience, which spans from five (5) to twelve (12) years.

This study used different materials and tools for data processing and presentation; part of the materials used is A-4 papers for questionnaire production, Google forms, Google spreadsheet, markers, pencils and biros. The Analytical package of Statistical tools of Statistical Package for Social Sciences Students (SPSS) as engaged in the processing of data collated from the respondents. Some of the tools include the Relative Agreement Index (RAI) and Mann-Whitney U test.

\subsection{Pearsons's Chi-Square Test and Student's T-Test}

Data processing with the Relative Agreement Index uses the following relation, Equation (1):

$$
\mathrm{RAI}=\sum \mathrm{WiA}[\mathrm{N}]
$$

where RAI = Relative Agreement Index; Wi = Weighted Sum; A = the number of items on the Likert scale of 1-5. $\mathrm{N}=$ individual weight of the scale item on the Likert scale 1-5. The component of the Likert Scale includes S.A.: Strongly Agree (5); A: Agree (4); SD: Strongly Disagree (2); D: Disagree (1); $\mathrm{N}$ : Neutral (3).

Similarly, the survey design method used in the study was found appropriate with a population comprised of 100 manufacturing companies of both small and large scales. Similarly, the sectionalized category of the clients was profiled and censored for data collection purposes. They include production manager-PM; quality control officer-QCO; production supervisor-PS; ICT officer-information communication technology officer. In this study. The category of respondents engaged in the study include the managers, officers and supervisors engaged in companies that are involved in consumer right products manufacturing, located at the Federal Capital Territory in Abuja and Lagos state Nigeria. Five (5) respondents volunteered for pretesting of the questionnaire for content validation; their observations were useful in recalibrating the questionnaire into the final form used for the analysis the view was supported in Refs. [13-15].

Summarily, the unique group of the sample used in the study includes a sample size of seventy-three (73) respondents. The sample cut across the cadre of managers and supervisors in product manufacturing companies, i.e., production manager- $\mathrm{PM}$; quality control officer- $\mathrm{QCO}$; production supervisor-PS; ICT officer-information communication technology officer.

\subsection{Questionnaire Design}

The data collection instrument adopted is a structured question designed in a Likert scale format of semantic rating scale 1-5. The design of the questionnaire was in a way that allows for easy collation of data. The questionnaire was divided into five sections that include Sections 1-5.

Section 1 focuses on the bio-data information of the respondents. Section 2 is about categories of production manager. Section 3 investigates the state of disruption in quality monitoring in industrial manufacturing. Section 4 is about the drivers of effective quality control system monitoring in intelligent manufacturing. Section 5 focuses on issues and challenges involved in quality control systems in 
intelligent manufacturing, while the Section 5 is on critical factors that influence an effective intelligent manufacturing system.

\subsection{Operationalization of Research Variables}

Delineation of essentials about variables' operationalization is in Table 1.

Table 1. The Workable Research Variables

\begin{tabular}{|c|c|c|c|}
\hline The Question, Analytical Method & Scale & Variables & Reference \\
\hline $\begin{array}{c}\text { Q1-5 Respondents' bio-data } \\
\text { information and work experience. } \\
\text { Analytical methods: } \\
\text { Descriptive Statistics Percentage. } \\
\text { Spearman Ranking. }\end{array}$ & $\begin{array}{l}\text { Ordinal, Numeric } \\
\text { Likert Scale }\end{array}$ & $\begin{array}{l}\text { Professional cadre, gender, types of managers, } \\
\text { qualification and cadre of managers on the } \\
\text { intelligent manufacturing system }\end{array}$ & [21] \\
\hline $\begin{array}{c}\text { Q6-14 Influence of Industry } 4.0 \text { (I4.0) } \\
\text { and lean thinking in technological } \\
\text { development for the construction } \\
\text { industry } \\
\text { Analytical methods: } \\
\text { Pearson's Chi-square, Kendal Tau teat } \\
\text { and Relative Agreement Index and } \\
\text { Spearman Ranking }\end{array}$ & Numeric, Likert scale & $\begin{array}{c}\text { Influence of Industry } 4.0 \text { (I4.0) and lean } \\
\text { thinking in technological development for the } \\
\text { construction industry }\end{array}$ & {$[20,23]$} \\
\hline $\begin{array}{c}\text { Q15-23 Examine disruptive } \\
\text { Construction } 4.0 \text { (C4.0) innovations } \\
\text { induced by Industry } 4.0 \text { (I4.0) } \\
\text { Analytical methods: } \\
\text { Pearson's Chi-square, Relative } \\
\text { Importance Index, Cronbach Alpha test } \\
\text { and Mann-Whitney U Test. }\end{array}$ & $\begin{array}{l}\text { Numeric } \\
\text { Likert scale }\end{array}$ & $\begin{array}{c}\text { Examining disruptive Industry } 4.0 \text { (I4.0) } \\
\text { innovations induced by Construction } 4.0 \text { (I4.0) } \\
\text { (contained in Table 2) }\end{array}$ & [21] \\
\hline $\begin{array}{l}\text { Q24-32 Identify the relevance of } \\
\text { Construction } 4.0 \text { (C4.0) and lean } \\
\text { thinking on construction projects } \\
\text { Analytical methods: } \\
\text { Pearson's Chi-square, Relative } \\
\text { Importance Index, Cronbach Alpha test } \\
\text { and Mann-Whitney U Test. }\end{array}$ & $\begin{array}{l}\text { Numeric } \\
\text { Likert scale }\end{array}$ & $\begin{array}{l}\text { Identify the relevance of Construction } 4.0(\mathrm{C} 4.0) \\
\text { and lean thinking on construction productivity } \\
\text { (contained in Tables } 8 \text { and 9) }\end{array}$ & {$[20,21]$} \\
\hline $\begin{array}{c}\text { Q33-42 To study areas of lean concept } \\
\text { influence on Construction } 4.0 \text { (C4.0). } \\
\text { Analytical methods used: Pearson's } \\
\text { Chi-square, Kendal Tau test, Relative } \\
\text { Satisfaction Index and Spearman } \\
\text { Ranking. }\end{array}$ & $\begin{array}{l}\text { Numeric } \\
\text { Likert Scale }\end{array}$ & $\begin{array}{c}\text { Censoring study areas of disruptions of lean } \\
\text { thinking concept in Industry } 4.0 \text { (I4.0) that } \\
\text { influence Construction4.0 (C4.0) enhancement } \\
\text { (expressed in Table } 4\end{array}$ & {$[20,24]$} \\
\hline $\begin{array}{l}\text { Q43-51 To examine adaptable industrial } \\
\text { application drivers in achieving } \\
\text { Construction } 4.0(\mathrm{C} 4.0) \\
\text { The analytical methods used: Relative } \\
\text { Effectiveness Index, Kendal Tau Test } \\
\text { and Spearman Ranking. }\end{array}$ & $\begin{array}{l}\text { Numeric } \\
\text { Likert Scale }\end{array}$ & $\begin{array}{c}\text { Adaptable industrial application drivers in } \\
\text { achieving Construction } 4.0(\mathrm{C} 4.0) \text { (contained in } \\
\text { Table 13) }\end{array}$ & [20] \\
\hline $\begin{array}{l}\text { Q52-60 To study the future of } \\
\text { Construction } 4.0(\mathrm{C} 4.0) \text { in achieving } \\
\text { automation goal in construction, } \\
\text { examine adaptable industrial } \\
\text { application drivers in achieving } \\
\text { Construction } 4.0(\mathrm{C} 4.0) \\
\text { Analytical methods: Relative } \\
\text { Effectiveness Index, Kendal Tau Test } \\
\text { and Spearman Ranking. }\end{array}$ & $\begin{array}{l}\text { Numeric } \\
\text { Likert Scale }\end{array}$ & $\begin{array}{c}\text { The future of Construction } 4.0(\mathrm{C} 4.0) \text { in } \\
\text { achieving automation goal in construction (is in } \\
\text { Table 9) }\end{array}$ & {$[12,16]$} \\
\hline $\begin{array}{c}\text { Q61-70 Identify Performance } \\
\text { expectation of lean thinking and } \\
\text { Industry } 4.0 \text { (I4.0) in construction } \\
\text { industry }\end{array}$ & $\begin{array}{l}\text { Numeric } \\
\text { Likert Scale }\end{array}$ & $\begin{array}{l}\text { Identify performance expectation of lean } \\
\text { thinking and Industry } 4.0 \text { (I4.0) in construction } \\
\text { industry (included in Tables 13-15) }\end{array}$ & {$[9,10]$} \\
\hline $\begin{array}{c}\text { Q71-81 Parameters for effective } \\
\text { integration of lean thinking approach } \\
\text { and Industry } 4.0\end{array}$ & $\begin{array}{l}\text { Numeric } \\
\text { Likert } \\
\text { Scale }\end{array}$ & $\begin{array}{l}\text { To document parameters for effective } \\
\text { integration of lean thinking approach and } \\
\text { Industry4.0 (expressed in Table 20) }\end{array}$ & [12] \\
\hline
\end{tabular}

The breakdown of the objectives and variables that formed the basis of data collated are grouped under questions 1 to 81. Each variables were examined for the scale, methodology and appropriate analytical tools. Eight research variables were mentioned in the text as illustrated in Table 1. 
The variables are generated on account of gaps identified through literatures reviewed. The variables dictates the type of data collated and analytical tools adopted for the research.

\subsection{Processing and Distribution of Questionnaire}

Processing and administration of the data collection were possible with the survey design method adopted. A purposive sampling technique was adopted to pull together the respondents, as mentioned earlier in Section 2.1.1. The respondents used for this study are the production personnel. At the same time, a total of one hundred (100) questionnaires designed in the Likert scale was eventually prepared and administered to one hundred (100) managers, supervisors and officers that constituted respondents. The completed and valid eighty (80) questionnaires, after collation and validation, were processed using methods similar to that adopted in [13-15].

\section{Results}

\subsection{Category of Respondents}

In the context of this study as presented in Table 2, a different types of respondents was engaged:

Table 2. Respondent classification.

\begin{tabular}{ccc}
\hline Respondent Cadre & Frequency & Percentage (\%) \\
\hline Production Supervisor & 30 & 30.00 \\
Production Manager & 30 & 30.00 \\
Quality Control Officer & 40 & 40.00 \\
Total & 100 & 100.00 \\
\hline
\end{tabular}

It includes thirty (30) production supervisors, thirty (30) production managers and forty (40) quality control officers. All respondents are directly involved in the production process of their various companies at the research location.

\subsection{Qualification of Respondents}

Manufacturing experience is a vital part of all technical research as present in Table 3; this is of the essence since the length of experience would position a respondent to respond as appropriate Level of experience would enable a respondent to contribute adequately towards a valid response to the administered questionnaire or interview. Respondents' level of experience is in Table 3.

Table 3. Respondents Manufacturing Experience.

\begin{tabular}{ccccc}
\hline Year Experience & PM & PS & QCO & Total \\
\hline $\mathbf{0 - 5}$ & 10 & 10 & 5 & 25 \\
$\mathbf{5 - 1 0}$ & 5 & 10 & 10 & 25 \\
$\mathbf{1 0 - 1 5}$ & 5 & 15 & - & 20 \\
$\mathbf{1 5}-\mathbf{2 0}$ & 10 & 10 & 10 & 30 \\
Total & 30 & 45 & 25 & 100 \\
\hline
\end{tabular}

Legend: production manager-PM; quality control officer-QCO; production supervisor-PS; ICT officer-information communication technology officer.

It was evident that the managers, supervisors and officers have more than one qualification. Among the 100 respondents sampled, 25 respondents belong to the cadre of those with $0-5$ and $5-10$ years of experience, respectively. Furthermore, 20 respondents belong to the category of 10-15 years of professional experience, while 30 respondents have 15 to 20 years of experience among production manager group.

Similarly, between 5 and 10 production managers have 0 to 20 years of professional experience; 10-15 production supervisors have $0-20$ years of experience; while 5 to 10 quality control officers have 
0 to 20 years of professional experience. Most of the production managers and supervisors have an adequate practical background which enables them to be suitable for the research. The outcome of the results structures presented in the table above is line with submissions in Refs. [7,8].

\subsection{Lean Thinking and Construction 4.0}

The lean thinking approach has a reputation for having the capability to bring about enhanced productivity. It contains a paradigm that has the potential to transform production and manufacturing landscape. The lean thinking approach provides a solution to problems in manufacturing and industrial production through the adaptability of conventional metric involved in the art and science of eliminating waste and redundancy. Some of the conventional metrics that could enhance productivity in construction work were censored and presented in Table 4.

Table 4. Areas of lean thinking that influence Construction 4.0.

\begin{tabular}{ccccccc}
\hline Lean-Thinking Parameters & PM & Rank & PS & Rank & QCO & Rank \\
\hline Lean Six Sigma & 0.76 & 1st & 0.75 & 1st & 0.65 & 1st \\
Value Identification & 0.76 & 1st & 0.68 & 2nd & 0.64 & 2nd \\
Mapping Value Stream & 0.68 & 3rd & 0.67 & 3rd & 0.64 & 2nd \\
Flow Creation & 0.67 & 4 th & 0.67 & 3rd & 0.62 & 4 th \\
Pull Establishment & 0.67 & 4 th & 0.67 & 3rd & 0.56 & 6 th \\
Constant Improvement & 0.60 & 6th & 0.62 & 6th & 0.57 & 5 th \\
Culture adoption & 0.59 & 7th & 0.57 & 7 th & 0.53 & 7 th \\
Value orientation & 0.58 & 8th & 0.55 & 8th & 0.53 & 7 th \\
\hline Production manager-PM; quality control officer-QCO; production supervisor-PS.
\end{tabular}

They include the following items: lean six sigma, value identification, mapping of value stream with relevant variables, flow creation, pull establishment, constant involvement, terotechnology, culture adoption and value orientation. With regard to the respondents view reflected in the parameters ranking, lean six sigma was unanimously ranked 1st by the three categories of the respondents (PM, PS and QCO) with Relative Agreement Index (RAI) values of 0.76, 0.75 and 0.65, respectively. Value identification is ranked second and third alongside mapping value stream by PM, PS and QCO with RAI 0.68, 0.67 and 0.64 , respectively. Flow creation is ranked 4th by PM and QCO. In contrast, a constant improvement, culture adoption and value orientation ranked sixth, seventh and eighth, respectively; the results structure illustrated in the table is corroborated in Ref. [23,24], which recommends the application of six sigma of lean thinking and technological innovations in achieving industrial application, through exploring the corroborating text further as regards six sigma.

The lean six sigma highest rating relates to the utility factor of the concept of lean thinking - for instance, the concept of lean six sigma utility when there are multi-objective activities in the production system including cost reduction, waste reduction, reduced cost and desired resource variation. In Ref. [23], it was posited that the concepts of lean thinking and six sigma have been in use over time, and they are being adopted in manufacturing firms and industries of different types to lower cost and ensure an improvement in quality benchmark and production quality. Often, this is achieved through enhanced productivity; therefore, the focus of organization management is ensuring reduction in production resource variation and production anomalies and defects through the concepts of lean thinking six sigma. In practical terms, Ref. [24] presented some parameters and tools of lean thinking including: continuous flow, lean machines and design simplicity, workplace network organization, production and machine parts, presentation, configurability of variables, product quality, maintainability, ease of access and ergonomics. Value identification and mapping are also essential tools in lean thinking adoption; the value of production should be identified first and then mapped, the actors and recipient should attest to the quality of the product and the details of their opinions should be documented. The view is supported in Ref. [16], submitting that in value identification, 
identification of end-users is vital. At the same time, the due emphasis is on having long-life end-users in focus. The product and the process should always be inclusive of life-long users by considering their specifications and requirements.

Similarly, culture establishment is vital alongside customer value, especially in supply chain management of the production or manufacturing process; this refers to value orientation in terms of communication with the stakeholders. For instance, in construction operations, what are the benchmarked client and project environment values? To what extent have they been harmonized and synchronized for project success? These questions can assist in modelling the value stream and culture inculcation for success in a production system. This fact is highlighted in Ref. [23], as enhancing communication with customers, optimizing transportation activity, people participating in problem-solving procedures and increasing the reliability of distribution operations are critical dimensions of the lean distribution paradigm. They are part of the pivotal culture that could assist in value orientation.

\subsection{Disruptions in Industry 4.0 and Construction 4.0 Advancement}

A paradigm shift is often necessary to create an improved system in engineering and other fields of endeavour, especially in a technological dynamics society such as the one in recent times. The construction field has witnessed tremendous changes in recent times, which has led to enhanced productivity. In the context of this study, some areas of disruptions in Industry 4.0 are in Table 5.

Table 5. Areas of disruptions in Industry 4.0 that influences Construction 4.0 advancement.

\begin{tabular}{cccc}
\hline Areas of Disruption in Industrial 4.0 & Mean & Relative Agreement Index & Rank \\
\hline Introduction of lean machines & 3.75 & 0.75 & 1st \\
Intelligent manufacturing and maintenance & 3.60 & 0.72 & 2nd \\
Intelligent system and smart Technologies & 3.60 & 0.72 & 2nd \\
System design and calibration & 3.60 & 0.72 & 2nd \\
Artificial intelligence & 2.65 & 0.53 & $3 \mathrm{rd}$ \\
Workplace organization & 2.65 & 0.53 & 3rd \\
Quality specification balancing & 2.60 & 0.52 & 5 th \\
System maintainability & 2.55 & 0.51 & 6 th \\
Ergonomic planning of space and tools allocation & 2.30 & 0.46 & 7 th \\
Value stream mapping & 2.25 & 0.45 & 8 th \\
Waste elimination & 2.00 & 0.40 &
\end{tabular}

The following factors are illustrated in Table 5 with a ranking order between first and third based on their RAI values of between 0.53 and 0.75 and statistical mean values: introduction of lean machines, intelligent manufacturing and maintenance intelligence systems and smart technology, design and calibration and workplace. The major areas profiled include system design, the introduction of lean machines, intelligent manufacturing and maintenance intelligence system and smart technology; design and calibration were ranked 2nd with RAI 0.72, while artificial intelligence and workplace organization were ranked 3rd with RAI scores of 0.53 , quality specification ranked 4th, system maintainability 5th, ergonomic planning of space and tools allocation 6th, value stream mapping 7 th and waste elimination ranked eighth. Introduction of lean machines was ranked 1st by the respondents. The research results are in line with submissions presented in Refs. [21-23], which corroborates the attributes of the lean concept in the areas of disruptions in Industry 4.0 that influence Construction 4.0, with the introduction of lean machines and application. The lean machine is a programmable machine that uses sensors for precision production and also for continuous flow, and the machine should also be designed for precision. Ref. [21], listed lean machine basics consist of the following: steady job and process flow, saving of factory floor space no excess production, no extra shelf and drawer space. The benefit of lean machines includes: one-at-a-time manufacture, quick production changeover, reduced waste easily modified and customizable production. Similarly, 
the advent of Industry 4.0 in the construction industry also comes in the form of introduction of an intelligent system, intelligent manufacturing and maintenance.

There is an intelligent system that is in modern intelligent buildings. In recent times, there has been the introduction of intelligent buildings in the form of electrical systems, smart doors, smart lighting systems, intelligent access control and perimeter security systems. Furthermore, in Refs. [21,23], systems of technological advancement are documented and have produced changes in construction processes in the building sector, such as; simulation, Industrial internet of things (IoT), cyber security, cloud storage, additive manufacturing and augmented reality. Moreover, there are systems of simulation that are conventionally used in design to achieve ergonomic planning of space and tools allocation and also for waste elimination; some of them include Revit, Primavera and Orion for cartographic designs. Some of the applications use the simulation system to illustrate how the system would behave real-time using 3D systems.

\subsection{Industry 4.0 and Lean Thinking in Technological Development for the Construction Industry}

Industry 4.0 has significantly impacted the construction terrains of developing and developed countries; there have been profound results of enhanced productivity on account of its introduction. Industry 4.0 has led to changes in the ways in which things are done in the construction field in the production and manufacturing sector of the economy, especially the construction industry. Therefore, the influence of Industry 4.0 in technological development for the construction industry is in Table 6.

Table 6. Influence of Industry 4.0 and lean thinking in Technological Development for Construction Industry.

\begin{tabular}{cccc}
\hline Influence of Industry 4.0 & Mean & RAI & Rank \\
\hline Introduction of automation & 3.90 & 0.78 & 1 st \\
Enhancement of the Planning system & 3.80 & 0.76 & 2nd \\
Change the order in design through 3D and going forward & 3.40 & 0.68 & 3rd \\
Intervention in the construction Costing process & 2.60 & 0.52 & 4 th \\
Project Control through adaptable Enterprise Resources System & 3.55 & 0.51 & 5 th \\
Evolution of new change system in procurement & 2.55 & 0.51 & 5 th \\
Evolution of adaptable system engineering for project specification & 2.55 & 0.51 & 5 th \\
Artificial intelligence, intelligent production, manufacturing and & 2.15 & 0.43 & 8th \\
maintenance advances & & & \\
\hline
\end{tabular}

The influence of Industry 4.0 in the construction industry is as presented in Table 6 . The influence mentioned includes the following: introduction of automation, enhancement of planning system, change the order in design through 3D and going forward, intervention in construction costing process, project control through adaptable enterprise resources system, the evolution of new change system in procurement, the evolution of adaptable system engineering for project specification and advance of artificial intelligence, intelligent production, manufacturing and maintenance introduction of automation is the most significant ranked influence with RAI value of 0.78 , there has been an increase in automation content of construction works, beginning from planning to the post-occupancy stage of the construction process. Automation has led to enhanced construction productivity, for instance Ref. [16] pointed out the introduction of the 3D approach in design and also the introduction of sophisticated soft other than traditional design method through AutoCAD and the like.

Furthermore, the enhancement of the planning system is ranked 2nd with an RAI value of 0.76; change in order of design through 3D with the prospect of $4 \mathrm{D}$ and $5 \mathrm{D}$ in view occupies the third rank. Additionally, intervention in construction costing process is ranked 3rd with an RAI of 0.68, and intervention in construction costing process is ranked fourth. Project control through adaptable enterprise resources system with an RAI of 0.52 is ranked 5th, the evolution of new change system in procurement with RAI is ranked 5th, the evolution of adaptable system engineering for project specification is on 5th rank. In contrast, the advance of artificial intelligence, intelligent production, manufacturing and maintenance with an RAI value of 0.43 are ranked eighth. The results presented 
in the table are in line with submissions on Industry 4.0 as in Ref. [22,23] as having the potential to enable global productivity and supply chain systems, and also to provide data for real-time assessment of productivity. Industry 4.0 has introduced a sensor powered machine with an intelligent system to enhance industrial productivity and variables measurement. Similarly, in Ref. [23] the advent of artificial intelligence is traced to the product manufacturing sector to Industrial 4.0 which tends to validate the findings of Industry 4.0 .

\subsection{Disruptive Innovation Gains towards Achieving Construction 4.0}

Disruptive innovation of Industry 4.0 is as illustrated in Table 7.

Table 7. Disruptive innovation of Industry 4.0, induced by Construction 4.0.

\begin{tabular}{cccc}
\hline Disruptive Parameters & Mean & RAI & Rank \\
\hline Investing in innovation in the industry & 3.75 & 0.75 & 1 st \\
Encouraging infrastructural development & 3.60 & 0.72 & 2nd \\
Bridging the technological and digital divide in the construction sector & 2.65 & 0.53 & 3rd \\
Developing sustainable construction Small Scale Enterprises & 2.60 & 0.52 & 4 th \\
Encouraging scientific research in the construction sector & 2.55 & 0.51 & 5 th \\
Innovative ideas that encourage construction sustainability & 2.30 & 0.46 & 6 th \\
Setting up a framework for disruptive innovation engagement & 2.25 & 0.45 & 7 th \\
Developing a strategy for technology transfer & 2.25 & 0.45 & 7 th \\
Setting up monitoring and control mechanisms while disruption lasts & 2.15 & 0.43 & 8 th \\
The mechanism for continuous review of progress achieved & 2.15 & 0.43 & 8 th \\
\hline
\end{tabular}

Disruptive innovation impact on construction development is highly essential; the innovative approaches adopted have led to the expansion of frontiers of knowledge and its application tremendously in the construction sector. Technologies from Europe, America and Asia have diffused rapidly into the scope of applications in the construction sectors worldwide-for instance, the introduction of smart construction from Asia and Korea Refs. [8,9]. Intelligent manufacturing from Europe and of recent artificial intelligence and robotics. Some robots deliver construction materials on sites, screed floors and render walls, laying asphalt and courses on roads, among others. Therefore, gains brought about by the technological disruption in order to create an atmosphere for Construction 4.0 are presented summarily in Table 7.

Investing in the innovation in the industry tops the ranking list of gains of disruption with a mean value of 3.75 and RAI value of 0.75 ; encouraging infrastructural development is ranked 2nd with mean and RAI values of 3.60 and 0.72 , respectively; bridging the technological and digital divide in the construction sector is ranked 3rd with mean and RAI values of 2.65 and 0.53 , respectively; developing sustainable construction Small Scale Manufacturing Enterprises ranked 4th with mean and RAI values of 2.60 and 0.52 , respectively; encouraging scientific research in the construction sector, with mean and RAI values of 2.55 and 0.51 , respectively, ranked 5th. Similarly, innovative ideas that encourage construction sustainability ranked 6th with an RAI of 0.46 ; setting up a framework for disruptive innovation engagement ranked 7th alongside developing a strategy for technology transfer with an RAI value of 0.45 ; while setting up monitoring and control mechanisms while disruption lasts and developing mechanism for continuous review of progress achieved were ranked 8th with mean and RAI values of 2.15 and 0.43 , respectively. Disruptive innovation of Industry 4.0 induced by Construction 4.0, as illustrated in the text, is in Refs. [6,7]. The Industry 4.0 revolution and the future of manufacturing execution system (MES) discussions are in the table as reflected in the opinion of Ref. [7] stressing the importance of the industrial revolution in setting the pace for industrial manufacturing.

\subsection{Influence and Relevance of Construction 4.0}

In Table 8 the respondents' PM, PS and QCO rated the following factors as high, being leading factors among influence and relevance of Construction 4.0. 
Table 8. Chi-square test statistics results.

\begin{tabular}{ccccccc}
\hline Parameters & Test & Asymptotic. Significant. & N & Test Statistics & DF & Decision \\
\hline PS & Chi-square & 0.328 & 13 & 6.077 & 6 & Retain the Null Hypothesis \\
PM & Chi-square & 0.329 & 13 & 6.923 & 6 & Retain the Null Hypothesis \\
QCO & Chi-square & 0.320 & 13 & 6.060 & 6 & Retain the Null Hypothesis \\
\hline
\end{tabular}

Production manager-PM; quality control officer-QCO; production supervisor-PS.

Industry 4.0 has led to the emergence of an enhanced production system, the introduction of automation in the construction process, elimination of construction waste, integration of information and human resources and development of calibration system for industrial quality measurement. Concerning the result presentation in Table 8, the emergence of the enhanced production system ranked highest by all the categories of the respondents with an average RAI score of 0.73 .

At the same time, the introduction of automation in the construction process was in the second position with RAI values of 0.66 and 0.74 . There was a paradigm shift in the construction process and integration of information and human resources, integration of information and human resources with an RAI score of 0.67 by PS and QCO supervisors. The resulting pattern presented, therefore, is in line with Refs. [17-19]. The studies lay out the relevance of Industry 4.0 including enhancement of construction productivity. Similarly, integration of lean and Industry 4.0 is key according to Refs. $[18,19]$ to transform the construction sector landscape. The studies of Refs. [18,19], therefore, are in tandem with parameters presented in the table above such as enhancement of human resources quality and standard, increase in the industrial gauge of tools and equipment and paradigm shift in the construction process.

Engagement of the Chi-square test on the data collated as regards the perspective of respondents on the interdependence of Industry 4.0 and productivity on construction sites is in the table. Chi-square test results on three categories of respondents are in Table 9.

Table 9. Influence and relevance of construction 4.0 and lean thinking concept in construction productivity.

\begin{tabular}{|c|c|c|c|c|c|c|}
\hline Influence Parameters & $\mathbf{P M}$ & Rank & PS & Rank & QCO & Rank \\
\hline Introduction of automation in the construction process & 0.66 & 2nd & 0.74 & 2nd & 0.73 & 1st \\
\hline Development of calibration system for industrial quality measurement & 0.61 & 8 th & 0.67 & 3 rd & 0.67 & 2nd \\
\hline Transfer of skill and knowledge sharing system & 0.57 & 9th & 0.61 & 9th & 0.61 & 8 th \\
\hline Introduction of robotics and artificial intelligence in construction & 0.57 & 9th & 0.56 & 6th & 0.56 & 9th \\
\hline A paradigm shift in the construction process & 0.62 & 7 th & 0.67 & $3 \mathrm{rd}$ & 0.66 & 5 th \\
\hline Integration of Information and human resources & 0.66 & 2nd & 0.67 & $3 \mathrm{rd}$ & 0.67 & 2nd \\
\hline Multi-disciplinary approach & 0.66 & 2nd & 0.66 & 4th & 0.61 & 8 th \\
\hline Increased Human and Nation GDP & 0.66 & 2nd & 0.66 & 4th & 0.56 & 9th \\
\hline Automation in building accessories & 0.66 & 2nd & 0.67 & $3 r d$ & 0.66 & 5 th \\
\hline
\end{tabular}

Production manager-PM; quality control officer-QCO; production supervisor—PS.

The Chi-square values of the three classes of respondents PS, PM and QCO are $0.328,0.329$ and 0.320 , respectively, greater than $p$-value 0.05 . The Null hypothesis is acceptable at 6 degrees of freedom; therefore, there is no statistical difference in the opinion of respondents on the influence of Industry 4.0 on construction productivity (Table 9). Interpreting the implications of the statistical results, the recommendation based on analytical results is for retaining the Null hypothesis-that is, there is no statistical difference in opinion of respondents on the influence of Industry 4.0 on construction productivity. The report is in tandem with the results in Refs. $[18,21]$ that outline the acceptance and rejection region of statistical propositions. In line with the results, all categories of respondents agreed to the fact that there is a strong influence and relevance of Construction 4.0 and the lean thinking 
concept in construction productivity. Some of the primary influences itemized in the context of this research include: the emergence of an enhanced production system, the introduction of automation in the construction process, elimination of construction waste and development of calibration system for industrial quality measurement among others.

In Table 9, analysis of reliability test was imperative on responses collated from project managers, project supervisors and quality control officers.

In Table 10 Cronbach results is presented.

Table 10. Cronbach alpha reliability test.

\begin{tabular}{ccc}
\hline Parameters & Cronbach Test Statistics & N \\
\hline Project Supervisor & 0.873 & 3 \\
Project Manager & 0.873 & 3 \\
Quality Control Officer & 0.873 & 3 \\
\hline
\end{tabular}

The Cronbach alpha test value is 0.873 ; the value is close to 1.00 , which indicates a high level of consistency in the data collection instrument and data collected. The data collection instruments follow the Likert scale order on a semantic rating scale from 1 to 5 , and the statistical value of 0.873 indicates a high level of consistency as indicated in Refs. [10,13].

The Mann-Whitney U result is as illustrated in Table 11, which was conducted on the ranking of variables by project managers, project supervisors and quality control officers.

Table 11. Mann-Whitney U test.

\begin{tabular}{cccccc}
\hline Parameters & Mann-Whitney-U Wilcoxon-W & Z & $\begin{array}{c}\text { Asymptotic. } \\
\text { Sig. (2 Tailed) }\end{array}$ & $\begin{array}{c}\text { Exact. Sign. } \\
\text { (2 Tailed) }\end{array}$ \\
\hline Project Supervisor & 0.000 & 1.000 & -1.500 & 0.132 & 0.333 \\
Project Manager & 0.000 & 1.000 & -1.00 & 0.137 & 1.000 \\
Quality Control Officer & 0.5000 & 1.500 & 0.000 & 1.000 & 1.000 \\
\hline
\end{tabular}

The Asymptotic Significance. (2-Tailed) value for PS, PM and QCO values are 0.132, 0.132 and 1.00 , respectively. The values are more significant than $p$-value 0.05 ; therefore, the rejection of the Null hypothesis is necessary, and there is an agreement in the ranking order of the respondent.

Similarly, results in Table 11 revealed that the responses are on the high side of the scale 1 to 5 . The majority of the respondents subscribed to scale scores of 4 and 5 rather than the lower one. Comparing the results of the analysis of the relevance of statistical results to the results presented indicate closeness in the ranking of the variables by respondents-for instance, variables 1 to 9 were ranked first and ninth together by the PM, PS and QCO, which indicates a correlation in their responses. The statistical presentation is similar in structure to that adopted in Refs. [10,11,13].

Analysis of Variance results spread is expressed in Table 12.

Table 12. Analysis of Variance (ANOVA) results.

\begin{tabular}{|c|c|c|c|c|c|c|}
\hline \multicolumn{2}{|c|}{ Opinion Parameters } & \multirow{2}{*}{$\begin{array}{c}\text { Sum of Squares } \\
0.000\end{array}$} & \multirow{2}{*}{$\begin{array}{c}\mathbf{d f} \\
1\end{array}$} & \multirow{2}{*}{$\begin{array}{c}\text { Mean Square } \\
0.000\end{array}$} & \multirow[t]{2}{*}{ Factor Loading } & \multirow[t]{2}{*}{ Sig. } \\
\hline & Between Groups & & & & & \\
\hline Enhanced Production System & Within Groups & 0.000 & 0 & & & \\
\hline \multirow{3}{*}{ Automation in construction } & Between Groups & 0.003 & 1 & 0.003 & & \\
\hline & Within Groups & 0.000 & 0 & & & \\
\hline & Total & 0.003 & 1 & & & \\
\hline \multirow[t]{2}{*}{ Waste Elimination } & Within Groups & 0.000 & 0 & & & \\
\hline & Total & 0.001 & 1 & & & \\
\hline
\end{tabular}


Table 12. Cont.

\begin{tabular}{|c|c|c|c|c|c|c|}
\hline \multicolumn{2}{|c|}{ Opinion Parameters } & \multirow{2}{*}{$\begin{array}{c}\text { Sum of Squares } \\
0.002\end{array}$} & \multirow{2}{*}{$\begin{array}{c}\mathrm{df} \\
1\end{array}$} & \multirow{2}{*}{$\begin{array}{c}\text { Mean Square } \\
0.002\end{array}$} & \multirow[t]{2}{*}{ Factor Loading } & \multirow[t]{2}{*}{ Sig. } \\
\hline \multirow{3}{*}{ System Calibration } & Between Groups & & & & & \\
\hline & Within Groups & 0.000 & 0 & & & \\
\hline & Total & 0.002 & 1 & & & \\
\hline \multirow{3}{*}{ Knowledge and skill transfer } & Between Groups & 0.001 & 1 & 0.001 & & \\
\hline & Within Groups & 0.000 & 0 & & & \\
\hline & Total & 0.001 & 1 & & & \\
\hline \multirow{3}{*}{ Introduction of Robotics } & Between Groups & 0.000 & 1 & 0.000 & & \\
\hline & Within Groups & 0.000 & 0 & & & \\
\hline & Total & 0.000 & 1 & & & \\
\hline \multirow{3}{*}{ Enhance human resources } & Between Groups & 0.000 & 1 & 0.000 & & \\
\hline & Within Groups & 0.000 & 0 & & & \\
\hline & Total & 0.000 & 1 & & & \\
\hline \multirow{3}{*}{ Increase in industrial gauge } & Between Groups & 0.001 & 1 & 0.001 & & \\
\hline & Within Groups & 0.000 & 0 & & & \\
\hline & Total & 0.001 & 1 & & & \\
\hline \multirow{3}{*}{ The paradigm shift in construction } & Between Groups & 0.001 & 1 & 0.001 & & \\
\hline & Within Groups & 0.000 & 0 & & & \\
\hline & Total & 0.001 & 1 & & & \\
\hline \multirow{3}{*}{$\begin{array}{c}\text { Integration of } \\
\text { information technology }\end{array}$} & Between Groups & 0.000 & 1 & 0.000 & & \\
\hline & Within Groups & 0.000 & 0 & & & \\
\hline & Total & 0.000 & 1 & & & \\
\hline \multirow{3}{*}{$\begin{array}{l}\text { A multi-disciplinary approach to } \\
\text { solving challenges }\end{array}$} & Between Groups & 0.000 & 1 & 0.000 & & \\
\hline & Within Groups & 0.000 & 0 & & & \\
\hline & Total & 0.000 & 1 & & & \\
\hline \multirow{3}{*}{ Increased human and Nations GDP } & Between Groups & 0.000 & 1 & 0.000 & & \\
\hline & Within Groups & 0.000 & 0 & & & \\
\hline & Total & 0.000 & 1 & & & \\
\hline \multirow{3}{*}{ Automation in building accessories } & Between Groups & 0.000 & 1 & 0.000 & & \\
\hline & Within Groups & 0.000 & 0 & & & \\
\hline & Total & 0.000 & 1 & & & \\
\hline
\end{tabular}

In Table 12 the mean square values for all the factors are less than 0.05 ; the $p$ values are less than 0.05 -i.e., $p<0.05$; therefore, the rejection of the Null hypothesis is necessary. Therefore, there is a homogeneity of opinion among the respondents on the relevance of Industry 4.0 on construction productivity. From the analysis results, mean square values ranged from 0.00 to 0.002 at 1 degree of freedom. This indicates the closeness of the tested parameters to the statistical $p$-value benchmark, which indicates closeness and skewness of test statistics to the agreement point of homogeneity of opinion. Therefore, the Null hypothesis which states that there is no homogeneity of opinion among the respondents on the relevance of Industry 4.0 on construction productivity is valid. The respondents agreed to the points that there is positive relevance in Industry 4.0 contribution to economic productivity; this is similar in structure to the system adopted in Ref. [25].

\subsection{Prominent Drivers in Achieving Construction 4.0 (C4.0)}

Table 13 shows the drivers that are pertinent to achieving C4.0.

Table 13. Industrial application drivers in achieving Construction 4.0.

\begin{tabular}{cccc}
\hline Drivers Parameters & Mean & RAI & Rank \\
\hline Good Industrial policy & 3.60 & 0.72 & 1st \\
Adequate Procurement Strategy & 3.45 & 0.69 & 2nd \\
Change management & 2.90 & 0.58 & 3rd \\
Technology transfer & 2.60 & 0.52 & 4 th \\
Software development and application & 2.55 & 0.51 & 5 th \\
Training and retaining & 2.35 & 0.47 & th \\
Elimination of digital divide barrier & 2.25 & 0.45 & 7th \\
\hline
\end{tabular}


The factors are the essentials that could help to achieve implementation of Construction 4.0. as presented in Table 13. The drivers include acceptable industrial policy, adequate procurement strategy, change management, technology transfer, software development and application, training and retraining and elimination of digital divide barrier. The most highly rated driver is acceptable industrial policy, which is ranked 1st with mean and RAI values of 3.60 and 0.72 , respectively. Adequate procurement strategy is ranked 2nd with mean and RAI values 3.45 and 0.69 , respectively; change management with mean and RAI values of 2.90 and 0.58 is ranked 3rd; while technology transfer is ranked 4th with an RAI value 0.52. Additionally, software development and application with an RAI value 0.51 are ranked 5th; training and retraining are ranked 6th with an RAI value of 0.476. In contrast, the elimination of the digital barrier with mean and RAI values of 2.25 and 0.45 , respectively, is ranked seventh. Policy formulation is essential and necessary to create a tenet that guides the way things operate; the policy provides a framework for operation, and in Ref. [28], it is posited that an adequate policy framework would accelerate the gains of Industry 4.0 for the creation of Construction 4.0.

The procurement strategy adopted for construction work is an important stage of construction work; it contains an embodiment of rules and conditions. There are different types of procurement system for engineering work-e.g., the traditional method, design and build system, labour only system and collaborative procurement system. Change management and technology transfer enable the stakeholders to effect relevant changes in the construction process. In change management, there is a need to map out goals and aspirations for Construction 4.0, then create an initial pilot project, define capability needed to execute the task, create support data, unroll the digital enterprise transformation and actively plan an approach that is ecosystem compliant in nature Refs. [16,26].

Training and retraining are required to sustain the tempo of change achieved. Elimination and extermination of the digital barrier are essential in achieving Construction 4.0 for industrial development. Because digitalization forms the basis of Industry 4.0 and Construction 4.0 achievement, the relationship that connects the driver, the goals, tools, routes, achievement and effect that depicts interconnection among the lean thinking concept of Industrial 4.0 and Construction 4.0 is in Figure 1.

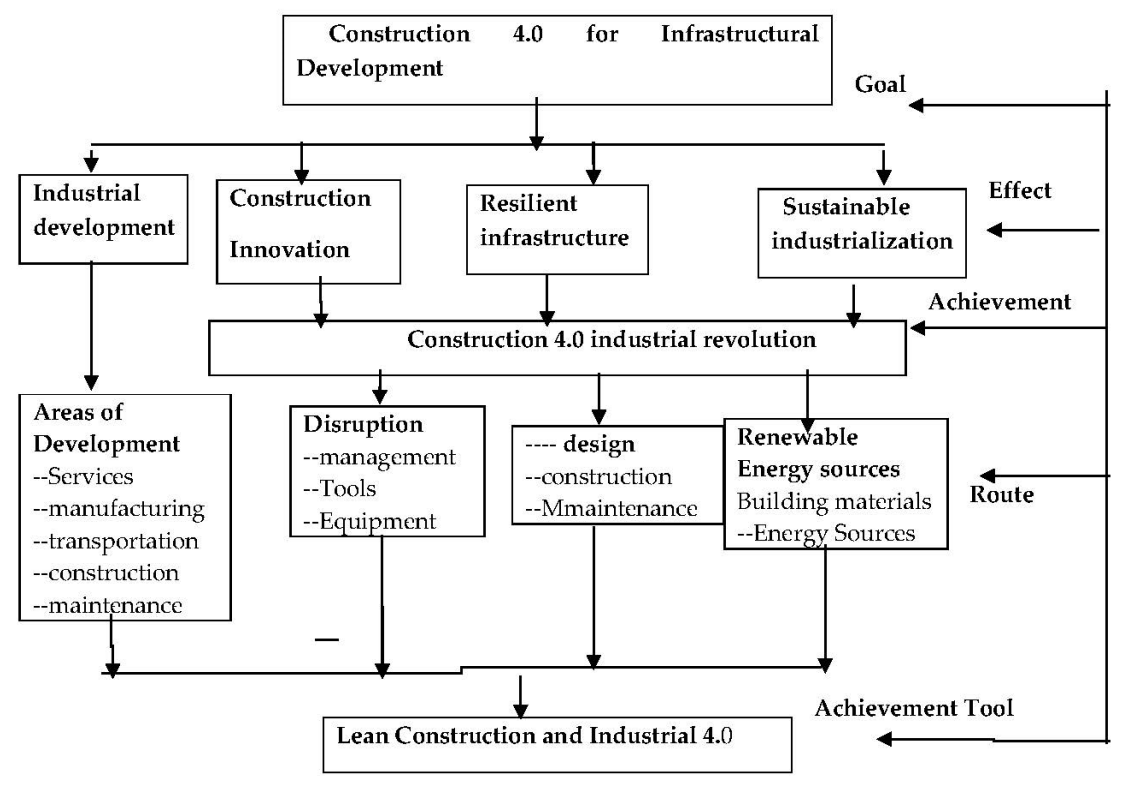

Figure 1. Interrelationship among disruptive innovations, Industry 4.0 and Construction 4.0.

The outcome of the interrelationship could define the horizon of future automation, as illustrated in Table 14. 
Table 14. Performance expectation of lean thinking and Industry 4.0 in the construction industry.

\begin{tabular}{ccccccc}
\hline Performance Expectation Parameters & PM & Rank & PS & Rank & QCO & Rank \\
\hline Rapid technological and industrial growth & 0.76 & 1 st & 0.76 & 1 st & 0.75 & 1 st \\
Waste elimination & 0.76 & 1 st & 0.76 & 1 st & 0.72 & 2nd \\
Enhanced construction productivity & 0.75 & 3rd & 0.75 & 3rd & 0.72 & 2nd \\
Vertical integration of concepts and ideas & 0.68 & 4 th & 0.67 & 4 th & 0.65 & 4 th \\
Evolution of new world order in industrial application & 0.67 & 5 th & 0.62 & 5 th & 0.59 & 5 th \\
Production of advance gadgets and Equipment & 0.63 & 6th & 0.61 & 6th & 0.52 & 6 th \\
Automation of industrial manufacturing components & 0.55 & 7 th & 0.59 & 7 th & 0.45 & 7th \\
Increase in construction GDP & 0.52 & 8th & 0.57 & 8th & 0.41 & 8th \\
\hline
\end{tabular}

Production manager-PM; quality control officer-QCO; production supervisor-PS.

\subsection{Achieving Automation Goal in Construction with Construction 4.0}

The interrelationship among disruptive innovations, Industry 4.0 and Construction 4.0, has the prospect of shaping the future of the construction industry. Considering Figure 1, the chart presents goals, achievement, effect, routes and achievement tools Refs. [23,24]. The goal is to achieve Construction 4.0, which refers to automation in construction. In order to achieve it, lean construction and Industry 4.0 are essential ingredients. Therefore, they represent a formidable tool of achievement. As posited by Refs. $[16,18,24]$, which validates the results presented in Table 14 of this study, the route to take in achieving it should embody areas such as design, benchmarked development areas, disruptive technologies and renewable energy sources.

Intelligent production, intelligent manufacturing, engaging state of the art tools in design and management are parts of the vital issue of consideration that is essential for consideration in creating an industrial revolution. Future of construction 4.0 is illustrated in Table 15.

Table 15. Future of Construction 4.0 in achieving automation goal in construction.

\begin{tabular}{ccccccc}
\hline Automation Goal in Construction & PM & Rank & PS & Rank & QCO & Rank \\
\hline Automated construction process & 0.75 & 1 st & 0.76 & 1st & 0.76 & 1st \\
Enhanced productivity & 0.67 & 2nd & 0.75 & 2nd & 0.75 & 2nd \\
Stakeholders inclusive participation & 0.62 & 3rd & 0.68 & 3rd & 0.68 & 3rd \\
Vertical product and material integration & 0.61 & 4 th & 0.67 & 4 th & 0.67 & 4 th \\
Technology and skill transfer & 0.59 & 5 th & 0.63 & 5 th & 0.63 & 5 th \\
Technology advancement & 0.57 & 6th & 0.56 & 6th & 0.56 & 6 th \\
Knowledge augmentation & 0.50 & 7 th & 0.56 & 6th & 0.55 & 7 th \\
Industrial expansion & 0.46 & 9th & 0.52 & 8th & 0.55 & 7 th \\
Enhancement of SME growth & 0.48 & 8th & 0.49 & 9th & 0.47 & 9th \\
\hline Production manager-PM; quality control officer-OCO; - Oroduction supervisor-PS. &
\end{tabular}

Production manager-PM; quality control officer-QCO; production supervisor-PS.

Furthermore, engaging tools tend to birth key achievements towards construction automation, resilient infrastructure, sustainable building, construction innovation and sustainable industrialization. This is also in line with submissions in Refs. [31,32,36,38] that highlighted the importance and contributions of the circular economy to economic and industrial development.

\subsection{Relationship between Lean Construction and Industrial 4.0 in Achieving Construction 4.0 Experience}

Figure 1 relates the interrelationship among the variables of innovation drivers, the innovation route, and achievement, the effect of the innovative approach and performance target or goal. Lean construction and Industry 4.0 are the innovative drivers drafted for the achievement of the goals. The innovative drivers for the attainment of industrial development as presented in this text are supported in the submissions on loop economy propounded under a circular economic situation as reflected by Refs. [26,31]. The circular economic situation, such as the lean concept, eliminates waste and encourages an innovative approach to achieve development. Meanwhile, the suggested route includes areas of development (services, manufacturing, transportation and construction)—disruptions, 
design and renewable energy sources-that is, an embodiment of circular economy as supported in Refs. [26,31,32], which relates how a circular economy can influence economic productivity, as illustrated in this study. Additionally, among the notable routes is innovation management; this is achievable through adoption of open innovation, and the open innovation approach enables access to management and requisite tools needed for the achievement of the goal; this idea is further supported in Refs. [36-38]. The studies recommended open innovation as a panacea to the development of construction SME which in turn brings about industrial development through Industry 4.0 technology spotlighting. The target of achievement is the Construction 4.0 industrial revolution. The ultimate goal is to achieve Construction 4.0 for infrastructural development and rapid urbanization. This, in turn, has potential to deliver sustainable development that encapsulates industrial development, construction innovation, resilient infrastructure and sustainable industrialization, in line with presentations in Refs. [3,6,43,44], which advocate sustainability concept adaptation for economic development.

\subsection{Performance Expectation of Lean Thinking and Industry 4.0}

Performance expectation of fusion of the lean thinking concept and Industry 4.0 for enhanced construction productivity is in Table 12. Rapid technological and industrial growth also formed part of suggestions as to the first performance expectation of the fusion of lean thinking and industry. Unanimous agreement of respondents occurred on the performance expectation through the rankings of PM and PS and QCO with an average RAI of 0.76. The second expectation is waste elimination with enhanced construction productivity with RAI 0.75 and 0.76 , respectively. Furthermore, vertical integration of concepts and ideas was ranked 4th, the evolution of new world order in industrial application ranked 5th a production of advance gadgets and equipment also ranked sixth. In contrast, automation of industrial manufacturing components and an increase in Gross Domestic Product (GDP) occupies seventh and eighth positions, respectively. The idea illustrated in the table above follows the opinion presented in Refs. [39-41]. Rapid technological and industrial growth, waste elimination and enhanced construction productivity are the cardinal targets of the lean thinking concept as intended in the context of this study.

\subsection{Chi-Square Test on Difference in the Rating of Performance Expectation of Project Professionals of Lean Thinking and Industry 4.0}

The Mann-Whitney $U$ result is as illustrated in Table 12 which was conducted on a ranking of variables by project managers, project supervisors and quality control officers. The Asymptotic Sig. (2-Tailed) values for PS, PM and QCO are $0.328,0.329$ and 0.320 , respectively. The results structure is in line with the opinion of the data analytics view expressed in Refs. [10,13]. The values are greater than $p$-value 0.05; therefore, the rejection of the Null hypothesis occurred at a specified degree of freedom, and there is an agreement in the ranking order of the respondent. Similarly, it revealed that the responses are on the high side of the scale of 1 to 5 , and the majority of the respondents subscribed to scale score four and 5 rather than the lower ones. The implication of the results lies in opinion stability on the part of the respondents. Evaluating their perspectives on the lean construction and Industry 4.0, the consensus on account of statistics results from the analysis points in the direction of PS, PM and QCO agreeing to the fact that the following factors are germane to the performance expectation of lean thinking and Industry 4.0. The factors include rapid technological and industrial growth, waste elimination and enhanced construction productivity, vertical integration of concepts and ideas, the evolution of new world order in industrial application, production of advance gadgets and equipment, automation of industrial manufacturing components and increase in construction GDP.

The Chi-square statistical test results are in Table 16. 
Table 16. Chi-square statistical analysis results from performance expectation of project professionals of lean thinking and Industry 4.0 .

\begin{tabular}{clccccc}
\hline Parameters & Test & Asymptotic. Sig. & N & Test Statistics & DF & Decision \\
\hline PS & Chi-square & 0.328 & 13 & 6.077 & 6 & Retain the Null Hypothesis \\
PM & Chi-square & 0.329 & 13 & 6.923 & 6 & Retain the Null Hypothesis \\
QCO & Chi-square & 0.320 & 13 & 6.060 & 6 & Retain the Null Hypothesis \\
\hline \multicolumn{7}{c}{}
\end{tabular}

The PS, PM and QCO has Chi-square asymptotic values of $0.328,0.329$ and 0.320 respectively. The values is greater than $p$-Value 0.05 at 6 Degree of freedom. Since the Chi-square calculated is greater than P-0.05, the Null hypothesis was retained. The implication of the test statistics results indicated that there is no significant difference in the opinion expressed by all the category of respondents as regards their performance expectation of lean thinking concept and industry 4.0.

The value of Cronbach Alpha test results on the responses collated indicated a statistical value of 0.865; this shows a high level of consistency in the data collation instrument of the data presented in Tables 16 and 17 and responses of the sampled project managers, project supervisors and quality control officers.

Table 17. Cronbach alpha reliability statistical test results.

\begin{tabular}{ccc}
\hline Parameters & Cronbach Test Statistics & N \\
\hline Project Supervisor & 0.865 & 3 \\
Project Manager & 0.865 & 3 \\
Quality Control Officer & 0.865 & 3 \\
\hline
\end{tabular}

The Cronbach alpha test value is 0.865 ; the value is close to 1.00 , which indicates a high level of consistency in the data collection instrument and data collected. In Refs. [24-26], it was submitted that the closer the calculated values to 1.0, the higher the reliability of variables measured. Therefore, in the context of this study, the validity of collated data from the respondents is established as presented in a similar study carried on data analytics of multi-criteria and Pareto optimum situations involving a selection of varieties of condition.

The Mann-Whitney U result is as presented in Table 18, which was conducted on a ranking of variables by project managers, project supervisors and quality control officers.

Table 18. Mann-Whitney $U$ test on performance expectation of lean thinking and Industry 4.0 in the construction industry.

\begin{tabular}{cccccc}
\hline Parameters & Mann-Whitney U & Wilcoxon-W & $\mathbf{Z}$ & $\begin{array}{c}\text { Asymptotic. } \\
\text { Sig. (2 Tailed) }\end{array}$ & Exact Sig. 2 Tailed \\
\hline Project Supervisor & 0.500 & 1.000 & -0.707 & 0.480 & 0.667 \\
Project Manager & 0.500 & 1.500 & -0.707 & 0.480 & 0.667 \\
Quality Control Officer & 0.500 & 1.500 & 0.000 & 1.000 & 1.000 \\
\hline
\end{tabular}

The Asymptotic Sig. (2-Tailed) values for PS, PM and QCO are 0.480, 0.480 and 1.00 is presented in Table 19.

Table 19. Chi-square statistical test on Null and test hypothesis on performance expectation of project professionals of lean thinking and Industry 4.0.

\begin{tabular}{|c|c|c|c|c|c|c|c|c|}
\hline Parameters & $\begin{array}{c}\text { Rapid } \\
\text { Technical and } \\
\text { Industrial } \\
\text { Growth }\end{array}$ & $\begin{array}{c}\text { Waste } \\
\text { Elimination }\end{array}$ & $\begin{array}{l}\text { Enhanced } \\
\text { Productivity }\end{array}$ & $\begin{array}{c}\text { Vertical } \\
\text { Integration of } \\
\text { Concepts }\end{array}$ & $\begin{array}{c}\text { Evolution of } \\
\text { New Industrial } \\
\text { Production } \\
\text { World Order }\end{array}$ & $\begin{array}{l}\text { Production } \\
\text { Advantage }\end{array}$ & $\begin{array}{l}\text { Automation } \\
\text { in Industrial } \\
\text { Applications }\end{array}$ & $\begin{array}{c}\text { Increased } \\
\text { Nations' GDP }\end{array}$ \\
\hline Chi-Square & 0.333 & 0.333 & 0.333 & 0.000 & 0.000 & 0.000 & 0.000 & 0.000 \\
\hline Df & 1 & 1 & 1 & 2 & 2 & 2 & 2 & 2 \\
\hline Asymp. Sig. & 0.564 & 0.564 & 0.564 & 1.000 & 1.000 & 1.000 & 1.000 & 1.000 \\
\hline
\end{tabular}


The values are more significant than $p$-value 0.05 ; therefore, the rejection of the Null hypothesis is necessary. Therefore, there is an agreement in the ranking order of the respondent. The Wilcoxon statistics results presented are a reflection of the stability of opinion on the part of the respondents despite being confronted with different conditions of the experiment. The Mann-Whitney U test results are comparable to the Wilconson statistics in the aspect of stability. The two statistical results dovetailed into validating the agreement of opinion among the respondents in place of examination under different variables and circumstances. This supports the Refs. $[10,13]$ data analytics of favourable and equiprobable favourable events. Similarly, it revealed that the responses are on the high side of the scale of 1 to 5 , and the majority of the respondents subscribed to scale score 4 and 5-i.e., "strongly agree" and "agree" - rather than the lower ones on the scale, which is in line with Refs. [10,13,27,28].

The Chi-square value of the eight parameters is as contained in Table 19, and ranked by the three types of respondents-PS, PM and QCO. The values span from 0.564 to 1.0.

The Asymptotic value is more significant than $p$-value 0.05 as shown in Table 20.

Table 20. Parameters for effective integrating of lean thinking approach and Industry 4.0.

\begin{tabular}{cccc}
\hline Integration Parameters & Mean & RAI & Rank \\
\hline Lean Thinking & & & \\
\hline Value chain sustainability & 3.85 & 0.77 & 1st \\
Delivery performance & 3.75 & 0.75 & 2nd \\
Appropriate production arrangement & 3.75 & 0.75 & 2nd \\
Eliminating raw materials wastage & 2.75 & 0.55 & 4 th \\
Site layout management & 2.50 & 0.50 & 5 th \\
Delivery management & 2.15 & 0.43 & 6 th \\
Production management & 2.10 & 0.42 & 7 th \\
Stock management & 2.10 & 0.42 & 8th \\
\hline Industry 4.0 & & & \\
Process simulation & 3.50 & 0.70 & 1st \\
\hline Vertical and horizontal function integration & 3.35 & 0.67 & 2nd \\
Internet-of-Things for component connectivity & 3.35 & 0.67 & 2nd \\
Collaborative procurement & 2.80 & 0.56 & 4 th \\
Implementing additive manufacturing & 2.80 & 0.56 & 4 th \\
Synchronization and integration of component & 2.80 & 0.56 & 4th \\
Machine-machine compatibility & 2.65 & 0.53 & 7th \\
Human-Machine compatibility & 2.65 & 0.53 & 7th \\
\hline
\end{tabular}

The acceptance of the Null hypothesis is imperative at 2 degrees of freedom; therefore, there is no statistical difference in the opinion of respondents. The results pattern obtained is consistent with the approach in Refs. [1,13].

There is no difference in optimistic expectation of performance enhancement in productivity through the integration of lean thinking and Industry 4.0 in the construction industry among respondents on the influence of Industry 4.0 on construction productivity. The implication of these statistical results on the empirical application of the research outcomes as presented in the tables is that the factors that are ranked highly should be explored and reinforced further for continue relevance. In contrast, those with low ranks deserved further investigation and possible restructure.

The Chi-square value of the eight parameters is as contained in Table 20, and ranked by the three types of respondents-PS, PM and QCO. The values span from 0.564 to 1.0. The Asymptotic value is more significant than $p$-value 0.05 . The Null hypothesis acceptance is essential at 2 degrees of freedom; therefore, there is no statistical difference in the opinions of respondents. There is no difference in positive expectation of performance enhancement in productivity through the integration of lean thinking and Industry 4.0 in the construction industry among respondents on the influence of Industry 4.0 on construction productivity. 


\subsection{Integrating Lean Thinking Approach and Industry 4.0}

In this section and as contained in Table 21, a strategy for integrating lean thinking approach and Industry 4.0 is presented.

Table 21. Parameters for effective integrating of lean thinking approach and Industry 4.0.

\begin{tabular}{cccc}
\hline Integration Parameters & Mean & RAI & Rank \\
\hline Lean Thinking & & & \\
\hline Value chain sustainability & 3.85 & 0.77 & 1 st \\
Delivery performance & 3.75 & 0.75 & 2nd \\
Appropriate production arrangement & 3.75 & 0.75 & 2nd \\
Eliminating raw materials wastage & 2.75 & 0.55 & 4 th \\
Site layout management & 2.50 & 0.50 & 5 th \\
Delivery management & 2.15 & 0.43 & 6 th \\
Production management & 2.10 & 0.42 & 7 th \\
Stock management & 2.10 & 0.42 & 8 th \\
\hline Industry 4.0 & & & \\
Process simulation & 3.50 & 0.70 & 1 st \\
\hline Vertical and horizontal function integration & 3.35 & 0.67 & $2 \mathrm{nd}$ \\
Internet-of-Things for component connectivity & 3.35 & 0.67 & $2 \mathrm{nd}$ \\
Collaborative procurement & 2.80 & 0.56 & 4 th \\
Implementing additive manufacturing & 2.80 & 0.56 & 4 th \\
Synchronization and integration of component & 2.80 & 0.56 & 4 th \\
Machine-machine compatibility & 2.65 & 0.53 & 7 th \\
Human-Machine compatibility & 2.65 & 0.53 & 7 th \\
\hline
\end{tabular}

The parameters for lean thinking integration include value chain sustainability, delivery performance, appropriate production arrangement, eliminating raw materials wastage, eliminating raw materials wastage, site layout management, delivery management, production management and stock management. Value chain sustainability is ranked 1st, with a mean value of 0.385 and RAI value of 0.77 . Delivery performance with a mean value of 3.75 and RAI value of 0.75 and appropriate production arrangement was ranked second. Layout management benchmarking is ranked 4th with a mean value 2.50 and RAI of 0.50. Eliminating raw materials wastage is ranked 4th with a mean value of 2.75 and RAI of 0.55 . The first step in lean thinking application in industry is to set up value points; this concerns the setting up of ideals, quality benchmarks, monitoring and control, performance expectation and appraisal of goals and achievements. Therefore, setting up a value chain and how to sustain it are the key. In industrial and production management, the value chain benchmarks include customer expectation, quality goals, performance benchmark, performance indication, zero defect, setting up of fault identification, treatment and mitigation, risk factors and product performance standard. This view is supported in Refs. $[15,16,21]$. Similarly, cardinal points that are germane to the integration of Industry 4.0 parameters to the achievement of success in Construction 4.0 are itemized and illustrated in Table 20 as well. The layout of opinions in Table 20 is consistent with findings of Refs. $[15,16,18]$. From the survey, the following ranking order emerged: process simulation is ranked 1st with a mean value 3.5 and RAI value of 0.7, vertical and horizontal function integration 2nd and Internet-of-Things for component connectivity 2 nd with a mean value of 3.35 and RAI of 0.67 , collaborative procurement occupied the fourth position on the rankings, while synchronization and integration of components occupied fourth with a mean value of 0.28 and RAI of 0.56 . Additionally, the following are ranked least: machine-machine compatibility and human-machine compatibility with mean and RAI values of 2.65 and 0.53 , respectively. In achieving Industry 4.0, a contingency approach and underline principles need to be followed; in line with the presentation in the survey presented in the tables, studies advocated the application of cutting edge practice in I4.0 application. In Ref. [14], the combination of a practice-based approach, dynamic capability approach, advanced manufacturing and sustainable development 
approach in the adoption and integration of I4.0 to achieve Construction 4.0 (C4.0) was advocated, this is in line with submissions in Table 4. Similarly, in Refs. [17,24,25] as presented in [13], it was submitted that ideals and standards are an essential aspects of innovation diffusion such as the case of I4.0.

Some of the ideals and maxims of Construction 4.0 include Internet of Things based manufacturing approaches such as refine, rescale, rethink and refurbish. It also includes reduce, refuse, reuse, recalibrate, repair, remodel, replace, replenish, remain, refactor remould, re-stress, recast reemphasize and recover.

Similarly, medium- and large-scale enterprises must recalibrate towards the adoption of Industry 4.0 (I4.0). This is necessary for effective diffusion of innovation and knowledge.

\section{Discussion}

The study has achieved the initial aim and objectives set at the outset. The influence of Industry 4.0 and lean thinking was the first objective of this study, and the influence came to the fore in this study; an illustration on the applicability of lean construction was one of the focal points of the presentation. The introduction of cutting edge tools is one of the significant contributions of Industry 4.0 to the technological development of manufacturing society. The lean thinking concept also contributed to the further development of operation and processes in the construction field. Industry 4.0 has contributed immensely to the influence of enhanced productivity in the construction industry. Part of the influence includes the introduction of automation, enhancement of planning system and change in the order in design through 3D. Intervention in construction costing process includes project control through adaptable enterprise resources system, the evolution of new change system in procurement, the evolution of adaptable system engineering for project specification and advance of artificial intelligence, intelligent production, manufacturing and maintenance.

The second objective concerns examining disruptive industrial innovations induced by Construction 4.0 (C4.0); the dominant innovations include: investing in the innovation in the industry, encouraging infrastructural development, bridging the technological and digital divide in the construction sector and developing sustainable construction SME. Innovation is one of the critical requirements in industrial development; innovation was a significant driver in new technologies that operate in the construction industry in the modern-day. Innovation in design is the driver of advanced methods of design and site monitoring. Therefore, the study advocated more investment in innovation development and diffusion in the construction industry. Considering the research outcome, construction SME virtually belongs to the group of a beneficiary of the various innovations. The relevance of Industry 4.0 and lean thinking in construction productivity dominate in objective 3 with a focus on the areas of disruption.

The emergence of the enhanced production system occupies a more prominent position than the introduction of automation in the construction process, elimination of construction waste and development of calibration system for industrial quality measurement. The study rated these factors highly on account of their utility. Lean thinking parameters offer the opportunity for process enhancement and development for quality output. Therefore, the adoption of the lean thinking concept and its enrichment could provide panacea out of low productivity. Waste elimination is one of the advantages of lean construction; the lean principle ensures waste elimination through the policy of zero defect adoption.

The exploration of the lean thinking concept fusion and enhancement with Industry 4.0 technology was carried out in objective 4. Breakthrough for the fulfilment of $\mathrm{C} 4.0$ emerged from lean six sigma, value identification and mapping of value stream for crucial adoption of the lean concept to create value for end-users in Construction 4.0. Therefore, effort concentration at value identification and mapping and configuration from a client, user and supplier perspective is essential. Some areas are significant for disruption consideration in the construction field and need further development and exploration. This includes the introduction of a lean machine, engaging intelligence manufacturing and intelligence maintenance Refs. [17,28,29,45]. 
Industrial application of drivers in achieving Construction 4.0 is part of the results of the analysis of the study as in objective 5 (five) and Table 14. The drivers are the catalyst for the effective administration of processes, and are, therefore, essential. Acceptable industrial policy emerged as the greatest of all the drivers-an organization that has an acceptable policy that controls operations. A good policy is necessary for control of decisions, rules and procedures; therefore, policymakers are essential links in the chains of intelligent manufacturing. Good procurement strategy always plays a vital role in product manufacturing and development. It tends to create a seamless production. Every production manager has obligations of ensuring a state of the art procurement strategy in industrial production, especially in the construction field. Change management is necessary for proper co-ordination of transferred technology transfer; this is a sure way to secure future technological innovation and diffusion Refs. [46-49].

Similarly, the future of Industry 4.0 influences in attaining the automation goal is in Table 15, as expressed in objective 6 . As one of the concluding statements of this study, achieving excellence in technology development is possible. The advent of Industry 4.0 from the outcome of the analysis has culminated in the introduction of automation, enhanced planning system, change in design protocol, construction and maintenance and enhanced production system, the introduction of automation in the construction process and elimination of construction waste Refs. $[7,13]$. However, the future of construction is here, as advocated in Refs. [12,30]. Automation is the future of the construction industry and achievable through consistent effort. The future is promising with high hopes for automation in design, construction and maintenance.

On this note, the performance expectation benchmark of lean thinking and Industry 4.0 integration occupies the seventh position among the set objectives as presented in Table 20. The expectation of all is construction productivity, which is a useful application of the lean thinking concept, and this can incorporate state of the art techniques and procedures as presented in the text. There is an expectation as regards design improvement, construction planning and intelligence component, among others. Rapid technological and industrial growth is the topmost expectation of professionals; Industry 4.0 has the potential to change technical components of construction in terms of provision of technological innovations. In contrast, the lean thinking concept can change the terrain of waste and loss elimination on-site in this study. The lean thinking concept enables waste elimination and zero-defect in construction and productivity enhancement.

Effective integration of the lean and Industry 4.0 is in Table 16 and objective 8.

This concerns a hybrid model that consists of lean thinking and Industry 4.0. It occurred through observation that the interlink between lean thinking and Industry 4.0 attribute can lead to improved construction productivity; an expectation of the fusion tends to create rapid technological and industrial growth, waste elimination with enhanced construction productivity, among others. The validity of the outcome of this research relies on applicability in expanding frontiers of knowledge in literary research, assistance to policymakers, assistance to the production managers and personnel, among others.

This study recommends further research in the following areas to advance literary contributions to knowledge in the academic world. These include the application of the lean concept in intelligent manufacturing and integration of lean and Industry 4.0 to achieve SDG goal 9.

Lean concept application is achievable through the application of the lean concept to the manufacturing sector. The attributes of lean concepts such as value mapping, value streaming, waste elimination, quality design and six sigma concept make the exploration of the fulfilment of sustainable development goal 9 possible. Sustainable development goal 9 concerns the provision of resilient infrastructure and sustainable industrial development. The characteristics of goal 9 mentioned are achievable through cutting edge technology. Precision and high-quality infrastructure are achievable through the tools of lean construction and deployment of intelligent tools and processes. Additionally, the integration of lean concept tools can provide a guide to achieving Industry 4.0 for technological development. Lean thinking would provide fine-tune the production process, eliminating waste and maintaining quality for the infrastructural provision and sustainable infrastructure production, 
which can become a reality through the engagement of Industry 4.0 technologies. Lean construction concepts can leverage on industrial development tools that are intelligently offered by Industry 4.0 technology to provide systems that could move the frontiers of industrial development to the next level. It can provide a panacea to sustainable industrial and manufacturing processes. Among parameters mentioned above are some areas of further research that are explorable for industrial development.

Author Contributions: Conceptualization, A.L.; methodology, A.L.; software, A.L.; validation, A.C.; formal analysis, A.L.; O.S.I.F.; investigation, O.J. and A.L.; data curation, O.J.; writing—original draft preparation, O.J. and A.L.; writing-review and editing, O.J. and visualization, O.S.I.F.; supervision, A.L.; project administration, A.L.; funding acquisition, A.L. All authors have read and agreed to the published version of the manuscript.

Funding: Covenant University, Ota, Ogun State Nigeria funded this research APC through the Center for Innovation and Research Development. Covenant University. Ota. Ogun State. Nigeria. http://www.covenantuniversity.com.

Acknowledgments: The support of Building Informatics group members of Building Technology Department of College of Science and Technology and Center for Innovation and Research Development Covenant University are appreciated for various contributions and for funding the APC.

Conflicts of Interest: The authors declare no conflict of interest in this research work. The funders had no role in study data collection, analyses, or interpretation of data; in the writing of the manuscript, or in the decision to publish the results.

\section{References}

1. Alaloul, W.S.; Liew, M.S.; Zawawi, N.A.W.; Mohammed, B.S.; Adamu, M. An Artificial neural networks $(\mathrm{ANN})$ model for evaluating construction project performance based on coordination factors. Cogent Eng. 2018, 5, 1507657. [CrossRef]

2. Mulgan, G. The Process of Social Innovation. Innov. Technol. Gov. Glob. 2006, 1, 145-162. [CrossRef]

3. Seyfang, G.; Haxeltine, A. Growing Grassroots Innovations: Exploring the Role of Community-Based Initiatives in Governing Sustainable Energy Transitions. Environ. Plan. C Gov. Policy 2012, 30, 381-400. [CrossRef]

4. Seyfang, G.; Park, J.J.; Smith, A. A thousand flowers blooming? An examination of community energy in the UK. Energy Policy 2013, 61, 977-989. [CrossRef]

5. Abbott, D. Applied Predictive Analytics: Principles and Techniques for the Professional Data Analyst; John Wiley: Hoboken, NJ, USA, 2014.

6. Adams, W.M. The Future of Sustainability: Re-Thinking Environment and Development in the Twenty-First Century. Report of the IUCN Renowned Thinkers Meeting; The World Conservation Union (IUCN): Gland, Switzerland, 2006; pp. 10-25.

7. Almada-Lobo, F. The Industry 4.0 revolution and the future of Manufacturing Execution Systems (MES). J. Innov. Manag. 2016, 3, 16-21. [CrossRef]

8. Andersson, P.; Mattsson, L.-G. Service innovations enabled by the "internet of things". Imp J. 2015, 9, 85-106. [CrossRef]

9. Arroyo, L.; Murillo, D.; Val, E. Trustful and Trustworthy: Manufacturing Trust in the Digital Era; ESADE: Barcelona, Spain, 2017; Volume 8, p. 220.

10. Wang, G.; Gunasekaran, A.; Ngai, E.W.; Papadopoulos, T. Big data analytics in logistics and supply chain management: Certain investigations for research and applications. Int. J. Prod. Econ. 2016, 176, 98-110. [CrossRef]

11. PwC. Industry 4.0: The Current State of Play in Flemish Manufacturing. Press Release. PwC. 31 March 2017. Available online: https://www.pwc.be/en/news-publications/press/2017/industry4-0-the-current-state-ofplay-in-flemish-manufacturing.html (accessed on 1 November 2017).

12. Bauer, H.; Patel, M.; Veira, J. The Internet of Things: Sizing Up the Opportunity (Technical Report). McKinsey Insights. December 2014. Available online: http://www.mckinsey.com/insights/high_tech_telecoms_internet/ the_internet_of_things_sizing_up_the_opportunity (accessed on 1 November 2017).

13. Hazen, B.T.; Boone, C.A.; Ezell, J.D.; Jones-Farmer, L.A. Data quality for data science, predictive analytics, and big data in supply chain management: An introduction to the problem and suggestions for research and applications. Int. J. Prod. Econ. 2014, 154, 72-80. [CrossRef] 
14. Hazen, B.T.; Mollenkopf, D.A.; Wang, Y. Remanufacturing for the circular economy an examination of consumer switching behaviour. Bus. Strat. Environ. 2017, 26, 451-464. [CrossRef]

15. Montori, F.; Bedogni, L.; Di Felice, M.; Bononi, L. Machine-to-machine wireless communication technologies for the Internet of Things: Taxonomy, comparison and open issues. Pervasive Mob. Comput. 2018, 50, 56-81. [CrossRef]

16. Karimi, J.; Somers, T.; Bhattacherjee, A. The Role of Information Systems Resources in ERP Capability Building and Business Process Outcomes. J. Manag. Inf. Syst. 2007, 24, 221-260. [CrossRef]

17. Koch, V.; Kuge, S.; Geissbauer, R.; Schrauf, S. Industry 4.0: Opportunities and Challenges of the Industrial Internet; PWC: London, UK, 2014; Volume 52, pp. 28-35.

18. Ibrahim, F.S.B.; Esa, M.B.; Kamal, E.B.M. Industrial revolution. Int. J. Sci. Technol. Res. 2019, 8, 1694-1700.

19. Rastogi, S. Construction 4.0: The 4th Generation Revolution. Indian Lean Construction Conference-ILCC 2017:C288; Kessington Press Ltd.: New York, NY, USA, 2017.

20. Pavlović, K.; Božanić, V. Lean and Six Sigma Concepts-Application in Pharmaceutical Industry. In Proceedings of the 4th International Quality Conference, Phuket, Thailand, 19 May 2014.

21. Reagan, S.S. Lean Manufacturing Principles. Ceram. Eng. Sci. Proc. 2008, 2, 13-18. [CrossRef]

22. Rubmann, M.; Lorenz, M.; Gerbert, P.; Waldner, M.; Justus, J.; Engel, P.; Harnissch, M. Industry 4.0: The Future of Productivity and Growth in Manufacturing Industries; BCG The Boston Consulting Group Consulting: Dallas, TX, USA, 2015; pp. 1-10.

23. Bag, S.; Gupta, S.; Kumar, S. Industry 4.0 adoption and 10R advance manufacturing capabilities for sustainable development. Int. J. Prod. Econ. 2021, 231, 107844. [CrossRef]

24. Prasad, S.; Sharma, S.K. Lean and Manufacturing: Concept and its Implementation in Operation Management. Int. J. Adv. Mech. Eng. 2014, 4, 2250-3234.

25. Womack, J.P.; Jones, D.T.; Roos, D. The Machine that Changed the World: The Story of Lean Production; Free Press, A Division of Simon \& Schuster, Inc.: London, UK, 1999; pp. 2-8.

26. Kirchherr, J.; Reike, D.; Hekkert, M. Conceptualizing the Circular Economy: An Analysis of 114 definitions. Resour. Conserv. Recycl. 2017, 127, 221-232. [CrossRef]

27. Frank, A.G.; Dalenogare, L.S.; Ayala, N.F. Industry 4.0 on procurement and supply management: A conceptual and qualitative analysis. Int. J. Prod. Econ. 2019, 210, 15-26. [CrossRef]

28. Mahfouz, A.; Arisha, A. Lean distribution concept, constructs and practices Conference. In Proceedings of the 20th International Annual EurOMA Conference-Operations Management at the Heart of the Recovery, Dublin, Ireland, 17 May 2013.

29. Morrar, R.; Arman, H. The Fourth Industrial Revolution (Industry 4.0): A Social Innovation Perspective. Technol. Innov. Manag. Rev. 2017, 7, 12-20. [CrossRef]

30. Pascall, T. Innovation and Industry 4.0. Disruption. 19 April 2019. Available online: https://disruptionhub. com/innovation-industry-4-0/ (accessed on 19 April 2019).

31. Andersen, M.S. An introductory note on the environmental economics of the circular economy. Sustain. Sci. 2006, 2, 133-140. [CrossRef]

32. Su, B.; Heshmati, A.; Geng, Y.; Yu, X. A review of the circular economy in China: Moving from rhetoric to implementation. J. Clean. Prod. 2013, 42, 215-227. [CrossRef]

33. Lieder, M.; Rashid, A. Towards circular economy implementation: A comprehensive review in context of manufacturing industry. J. Clean. Prod. 2016, 115, 36-51. [CrossRef]

34. European Commission. Closing the loop-An E.U. action plan for the Circular Economy, Com. In 614 Communication from the Commission to the European Parliament, the Council, the European Economic and Social Committee and the Committee of the Regions; European Commission: Brussels, Belgium, 2015.

35. METI. Handbook on Resource Recycling Legislation and 3R Initiatives. Japanese Ministry of Economy; Trade and Industry: Tokyo, Japan, 2004.

36. Geissdoerfer, M.; Savage, P.; Bocken, N.M.P.; Hultink, E.J. The Circular Economy-A new sustainability paradigm? J. Clean. Prod. 2016. [CrossRef]

37. Tödtling, F.; Tripp, M. Does one size fit all? Towards a differentiated regional innovation policy Approach. Res. Policy 2005, 34, 1203-1219. [CrossRef]

38. Rahman, H.; Ramos, I. Open Innovation in SMEs: From Closed Boundaries to Networked Paradigm. Issues Inf. Sci. Inf. Technol. 2010, 7, 471-487. [CrossRef]

39. Dahlander, L.; Gann, D.M. How to open innovation? Res. Policy 2010, 39, 699-709. [CrossRef] 
40. Miles, R.E.; Miles, G.; Snow, C.C. Collaborative Entrepreneurship: How Communities of Networked Firms use Continuous Innovation to Create Economic Wealth; Stanford Business Books: Stanford, UK, 2005.

41. Freitas, I.M.B.; Marques, R.A.; Silva, E.M.P. University-industry Collaboration and innovation in emergent and mature industries in newly industrialized countries. Res. Policy 2013, 42, 443-445. [CrossRef]

42. Lichtenthaler, U. Open Innovation in Practice: An Analysis of Strategic Approaches to Technology Transactions. IEEE Trans. Eng. Manag. 2008, 55, 148-157. [CrossRef]

43. De Oliveira, L.S.; Echeveste, M.E.S.; Cortimiglia, M.N.; Gonçalves, C.G.C. Analysis of determinants for Open Innovation implementation in Regional Innovation Systems. Rev. Adm. Innov. Rai 2017, 14, 119-129. [CrossRef]

44. Poon, A. The meaning of sustainable development. In Proceedings of the Trade and Development Implications of Tourism Services for Developing Countries: UNCTAD XII Pre-Event, Geneva, Switzerland, 19-20 November 2007.

45. Stoddart, H. A Pocket Guide to Sustainable Development Governance; Stakeholder Forum: London, UK, 2011.

46. Brown, R.; Mason, C.M. Raising the batting average: Re-orientating regional industrial policy to generate more high growth firms. Local Econ. J. Local Econ. Policy Unit 2012, 27, 33-49. [CrossRef]

47. Akinbo, T.F.; Fagbenle, I.O.; Amusan, L.; Afolabi, A.O.; Tunji-Olayeni, P.F. Exploratory Study on Sustainability Practices of Localized and Expatriate Construction Businesses. Int. J. Civ. Eng. Technol. 2019, 9, 1446-1456.

48. Omuh, I.O.; Ojelabi, R.A.; Tunji-Olayeni, P.F.; Afolabi, A.; Amusan, L.; Okanlawon, B. Green Building Design and Adoption: Occupants Reflections. Int. J. Mech. Eng. Technol. (IJMET) 2018, 9, 1345-1352.

49. Ojelabi, R.; Oyeyipo, O.; Afolabi, A.; Amusan, L. Presence of Social Client Relationship Management within the Nigerian Construction Industry. Buildings 2018, 8, 60. [CrossRef]

Publisher's Note: MDPI stays neutral with regard to jurisdictional claims in published maps and institutional affiliations. 